\title{
MANAJEMEN PERSONALIA DALAM MENINGKATKAN KEDISIPLINAN GURU DI MIN KAMAL BANGKALAN
}

\author{
Ali Wafa Mukhtar \\ Program Studi Manajemen Pendidikan Pasca Sarjana Unesa \\ aliwafa.mukhtar@gmail.com
}

\begin{abstract}
Abstrak: Guru memegang peranan penting dalam menciptakan sumber daya manusia pendidikan yang handal, sehingga diperlukan manajemen personalia yang baik bagi sekolah dalam menciptakan guru yang dengan kedisiplinan yang baik. Penelitian ini bertujuan untuk mengevaluasi manajemen personalia dan kedisiplinan guru di MIN Kamal Bangkalan. Penelitian ini termasuk penelitian analisis deskriptif dengan pendekatan kualitatif. Teknik pengumpulan data yang digunakan adalah: (1) wawancara mendalam; (2) observasi partisipan; (3) dokumentasi. Sedangkan untuk teknik analisis datanya yang digunakan adalah: (1) reduksi data; (2) penyajian data; dan (3) kesimpulan atau verifikasi. Pengecekan data yang digunakan dalam penelitian ini adalah: (1) credibility; (2) transferability; (3) dependability; dan (4) confirmability. Berdasarkan hasil penelitian dan pembahasan dapat disimpulkan bahwa manajemen personalia yang berkaitan dengan pengembangan guru, lingkungan yang kondusif, insentif dan merit system di MIN Kamal Bangkalan sudah dilaksanakan dengan baik, hanya perlu perbaikan dalam proses perencanaan hingga monitoring dalam program insentif dan merit system. Pelaksanaan kedisiplinan guru juga sudah dilaksanakan dengan baik. Upaya untuk meningkatkan kapasitas guru memang harus dilaksakan dengan manajemen peronalia yang baik yang nantinya akan menghasilkan kedisiplinan guru yang baik.
\end{abstract}

Kata Kunci : Manajemen Personalia, Kedisiplinan Guru, Peningkatan Kedisiplinan Guru.

Abstract: Teachers play an important role in creating a reliable human resources education, so it takes good management personnel for schools in creating teachers with good discipline. This study aims to evaluate personnel management and teacher discipline in MIN Kamal Bangkalan. This research includes descriptive analysis research with qualitative approach, data collection techniques used are: (1) in-depth interview; (2) participant observation; (3) documentation. As for the data analysis techniques used are: (1) data reduction; (2) presentation of data; And (3) conclusions or verifications. Checking data used in this research are: (1) credibility; (2) transferability; (3) dependability; And (4) confirmability. Based on the results of research and discussion it can be concluded that personnel management related to teacher development, conducive environment, incentive and merit system in MIN Kamal Bangkalan has been implemented well, only need improvement in planning process until monitoring in incentive program and merit system. The implementation of teacher discipline has also been well implemented. Efforts to improve the capacity of teachers should be implemented with good peronal management that will result in good teacher discipline.

Keywords: Personnel Management, Teacher's Discipline, Teacher's Discipline Improvement. 

Sekolah merupakan garda terdepan pendidikan yang keberadaanya sering mendapatkan sorotan dari berbagai kalangan menyangkut mutu lulusan dan mutu pengelolaan pendidikan. Adanya sorotan tersebut, sebaiknya sekolah melakukan perbaikan dalam pengelolaan personalia guru dan tata usaha yang lebih profesional yang dinamis. Adanya sorotan tentang kualitas lembaga pendidikan tentang mutu lulusan tersebut penyebabkan tugas sebagai kepala sekolah dalam pengelolaan personalia semakin berat dan mengoptimalkan kinerja guru. Pengelolaan personalia yang kurang optimal merupakan masalah yang bisa menghambat pembangunan dan perkembangan perekonomian nasional, penataan sumber daya manusia perlu diupayakan secara bertahap dan berkesinambungan melalui sistem pendidikan yang berkualitas baik pada jalur pendidikan formal, informal, maupun non formal, mulai dari dasar sampai perguruan tinggi (Mulyasa, 2004: 127).

\section{Gaffar}

\section{mengemukakan}

(Mulyasa, bahwa

2004:19) manajemen pendidikan mengandung arti sebagai suatu proses kerjasama yang sistematis, sistemik, dan komprehensif dalam rangka mewujudkan tujuan pendidikan nasional. Hal tersebut juga disampaikan Suryobroto (2004: 15), menyatakan bahwa manajemen pendidikan adalah suatu proses untuk mencapai tujuan pendidikan yang terdiri atas: perencanaan, pengorganisasian, pengarahan, pemantauan, dan penilaian. Hal ini diperkuat oleh sistem pendidikan nasional menyebutkan bahwa tenaga pendidik dan kependidikan merupakan faktor yang paling dominan dalam menentukan keberhasilan terhadap kegiatan proses pendidikan di sekolah. Pengembangan guru dan staf merupakan pekerjaan yang harus dilakukan kepala sekolah dalam manajemen pesonalia pendidikan, yang bertujuan untuk memperdayagunakan guru dan staf secara efektif dan efisien untuk mencapai hasil yang optimal (Mulyasa, 2004: 24). Dari pernyataan di atas dalam pencapaian tujuan nasional diperlukan manajemen personalia dan peningkatan kinerja guru, serta dengan berkualitasnya tenaga pendidik dan kependidikan akan menjalankan fungsinya secara professional.

Pendidikan nasional terutama pendidikan dasar dan menengah selama sepuluh tahun mengalami kondisi yang kurang bagus. The Learning Curve 2014, yang baru dirilis oleh Pearson memposisikan pendidikan Indonesia sebagai sebuah Negara dengan sistem pendidikan berada pada urutan terakhir dari 40 negara. Posisi pendidikan Indonesia pada tahun yang lalu berada pada urutan 39 dari 40 negara Berdasarkan assesment internasional, yaitu test PISA (membaca) dan TIMMS (bernalar) posisi siswa Indonesia di rangking bawah (2003, 2006, 2009, dan 2012), sehingga kualitas siswa di Indonesia dapat dikatakan terbelakang apabila berkaca pada hasil assesment tersebut. Tidak berbeda jauh dengan kualitas siswanya, kualitas guru di Indonesia juga tergolong rendah, selain itu menurut penelitian World Bank (2012) kualitas guru Indonesia terendah (urutan 12 dari 12 negara Asia), bahkan hasil UKG hanya 4,3. Kualitas guru di Indonesia sangat memprihatinkan dan banyak yang tidak pernah mengikuti pelatihan sehingga kualitasnya tidak ada peningkatan (Listyarti, 2014: 4).

Para tenaga kependidikan juga jarang menjalani orientasi dan memperoleh pendidikan yang komprehensif, serta kurangnya tenaga yang terlatih dibanding dengan percepatan pembaharuan pendidikan (Depdiknas, 2000: 12). Penelitian yang dilakukan oleh Balitbang Kemendikbud pada tahun 2014 ini merupakan salah satu studi ketidakhadiran guru yang paling menyeluruh dan berskala. Penelitian ini mengungkapkan bahwa satu dari sepuluh guru tidak hadir di sekolah. 
Selain itu juga guru-guru yang dijadwalkan mengajar $12 \%-14 \%$ diantaranya ditemukan ada di sekolah tetapi tidak berada di dalam kelas. Guru-guru yang tidak hadir dalam kelas sangat sering ditemukan berada di sekolah, namun tidak mengerjakan kegiatan yang berhubungan dengan kegiatan akademis ataupun administratif. Dari penelitian tersebut bisa disimpulkan bahwa tingkat kedisiplinan guru dalam melaksanakan tugasnya masih rendah. Oleh karena itu, diperlukan peran serta masyarakat untuk mengawasi dan melaporkan tingkat kehadiran dan kinerja pelayanan guru di daerah masing-masing.

Pengelolaan personalia di sekolah khususnya di sekolah dasar belum dilaksanakan secara optimal, maka perlu perhatian dari pemerintah untuk masalah manajemen personalia tersebut. Sebagian besar sekolah dasar di Kabupaten Bangkalan jumlah personalia masih kurang, baik tenaga pendidik maupun tenaga kependidikan. Guru professional dan guru yang berkualifikasi sarjana juga masih kurang, maka banyak sekolah yang mengangkat guru wiyatabakti (honorer) yang belum berkualifikasi sarjana. Hal tersebut bertentangan dengan undangundang No.14 Tahun 2005 tentang guru dan dosen dan Peraturan Pemerintah No. 74 Tahun 2008 tentang guru. Salah satu isi peraturan tersebut menyebutkan bahwa seorang guru harus mempunyai kualifikasi pendidikan minimal Sarjana (S1) atau D-IV.

Madrasah Ibtidaiyah Negeri (MIN) Kamal yang berada di Jalan Trunojoyo No. 5 Desa Banyu Ajuh Kecamatan Kamal Kabupaten Bangkalan. Dari aspek letak geografis sekolah ini tidak terletak di pinggiran Kecamatan Kamal Bangkalan, butuh waktu 30 menit untuk sampai ke pusat kota Bangkalan. Pengelolaan personalia Madrasah Ibtidaiyah Negeri (MIN) Kamal sudah dilaksanakan dengan baik. Hal ini ditandai dengan pembelajaran secara utuh dan komprehensif sudah bisa diimplementasikan secara optimal. Selain itu, pengembangan guru juga sudah optimal yang ditandai dengan pengiriman para guru dalam rangka untuk peningkatan kompetensi, selain itu pemberian penghargaan dan bonus untuk guru yang berprestasi juga sudah dilaksanakan. Keadaan seperti ini yang mengakibatkan motivasi guru untuk berprestasi sudah baik, bahkan guru melaksanakan tupoksinya dengan sangat baik pula. Sekolah ini diisi oleh aneka ragam usia guru, ada yang senior dan ada pula yang masih muda. Keadaan pelaksanaan manajemen personalia seperti di atas sedikit banyak mempengaruhi tentang kualitas di Madrasah Ibtidaiyah Negeri (MIN) Kamal itu sendiri.

Dari hasil studi pendahuluan di sekolah, bahwa Madrasah Ibtidaiyah Negeri (MIN) Kamal Bangkalan merupakan sekolah yang berdirinya Madrasah Ibtidaiyah Negeri Kamal Bangkalan berdiri pada tahun 1978. Pelopor pendiri madrasah ini adalah Bpk. Brawi sebagai pemilik tanah kemudian diwakafkan kepada Kemenag untuk lebih dikembangkan menjadi madrasah yang lebih maju.. Dengan ini dapat dijelaskan sebagai berikut. Pertama, menurut beberapa guru Madrasah Ibtidaiyah Negeri (MIN) Kamal Bangkalan bahwa manajemen personalia sudah dilaksanakan. Misalnya dengan mengirimkan guru untuk mengikuti workshop atau seminar. Selain pengembangan guru, misalnya rekruitmen, penempatan, penghargaan, dan merit system juga sudah dilaksanakan, serta keberadaan lingkungan yang kondusif yang sudah baik.

Kedua, kedisiplinan guru menurut salah satu guru senior bahwa enam bulan terakhir mengalami peningkatan khususnya keterlambatan kehadiran guru di sekolah maupun pada saat memulai pembelajaran di kelas. Kedisiplinan dalam berpakaian juga sudah baik, salah satunya ditandai kelengkapan atribut dan kerapian seragam. Penggunaan waktu di luar pembelajaran juga sudah berjalan efektif. 
Ketiga, manajemen personalia di Madrasah Ibtidaiyah Negeri (MIN) Kamal Bangkalan berdasarkan studi dokumen pada 8 standar pendidikan khususnya dokumen standar pendidik dan tenaga kependidikan ditemukan pola pengembangan guru yang sdah berjalan optimal, bahkan penghargaan dan merit system juga sudah diterapkan dengan aneka ragam pendekatan. Keempat, berdasarkan studi dokumen yang diperoleh di lapangan khususnya tentang manajemen personalia memang sudah optimal. Hanya saja keberadaan pengembangan tersebut yang dilaksanakan oleh pihak Madrasah Ibtidaiyah Negeri (MIN) Kamal Bangkalan memerlukan evaluasi yang nantinya akan dijadikan masukan bagi pengembangan manajemen personalia yang lebih baik ke depannya. Salah satu cotohnya adalah dokumen kedisiplinan guru, keterlambatan guru tiba di sekolah atau keterlambatan kehadiran di kelas untuk memulai pembelajaran, pelanggaran kode etik guru, pelanggaran kerapian berpakaian dan yang lain juga sudah berjalan dengan baik.

Peraturan di Madrasah Ibtidaiyah Negeri (MIN) Kamal Bangkalan berkenaan dengan kehadiran guru di kelas yaitu pukul 06.50 WIB, pada kenyataannya keterlambatan guru dalam kehadiran di kelas untuk memulai pelajaran masih pada taraf kewajaran. Hal ini dapat dijelaskan pada tabel sebagai berikut.

Tabel 1 Rekapitulasi Tingkat Keterlambatan Guru

\begin{tabular}{cc}
\hline \multicolumn{2}{c}{ Waktu Keterlambatan/Jumlah/Prosentase } \\
\hline 10 Menit s.d. 15 Menit & Lebih dari 15 Menit \\
\hline 10 & 6 \\
\hline $62,5 \%$ & $37,5 \%$ \\
\hline
\end{tabular}

Sumber: Dokumen Daftar Kehadiran Guru

Berdasarkan tabel di atas dapat dipahami bahwa Guru-guru Madrasah Ibtidaiyah Negeri (MIN) Kamal Bangkalan masih harus perlu dikembangkan semangat dan kedisiplinan guru yang tinggi yang dijadikan landasan seluruh elemen di Madrasah Ibtidaiyah Negeri (MIN) Kamal Bangkalan yang selalu berupaya dalam kemajuan sekolah. Selain manajemen personalia, ada beberapa permasalahan yang menjadi kendala yaitu kedisiplinan guru seperti yang dijelaskan dengan tabel di atas.

Berdasarkan kendala di atas, sekolah dituntut mempunyai komitmen yang tinggi dalam pengembangan dan kedisiplinan guru untuk meningkatkan pelayanan pendidikan yang prima. Oleh karena itu, diadakan pengembangan dan peningkatan kinerja guru yang maksimal melalui melalui on job training dan in service training yang sudah dilaksanakan oleh Madrasah Ibtidaiyah Negeri (MIN) Kamal Bangkalan. Hal ini juga disampaikan oleh Pidarta (2007: 86) bahwa untuk meningkatkan aktivitasaktivitas yang dapat mendatangkan kepuasan kerja dengan melayani kebutuhan-kebutuhan para guru. Dari pernyataan di atas bahwa guru harus meningkatkan kinerja dan meningkatkan kompetensi untuk mencapai kepuasan kerja dalam melaksanakan tugas sehari-hari.

Mengenai keunikan, ketertarikan, dan urgensinya dapat dijelaskan sebagai berikut. Dapat dilihat keunikannya, personalia di Madrasah Ibtidaiyah Negeri (MIN) Kamal Bangkalan dikelola dengan maksimal yang menjadikan sekolah tersebut sebagai Madrasah Ibtidaiyah Negeri (MIN) Model yang sudah barang tentu menjadikan sekolah tersebut sebagai percontohan pengembangan pendidikan yang baik bagi sekolah lainnya. Di daerah Bangkalan hanya sedikit sekolah yang dijadikan sekolah model atau percontohan pengembangan personalia dan kedisiplinan guru, kebanyakan sekolah hanya berjalan dengan sendirinya, maka peneliti tertarik untuk meneliti pelaksanaan manajemen personalia dalam meningkatkan kedisiplinan guru di Madrasah Ibtidaiyah Negeri (MIN) Kamal Bangkalan. Urgensi masalah 
tersebut adalah tenaga pendidik merupakan ujung tombak kemajuan pendidikan, sehingga bila tidak dilakukan pengembangan akan berdampak lambatnya kemajuan pendidikan dan dimungkinkan bisa mengalami kemunduran dalam dunia pendidikan.

Pelaksanaan manajemen personalia dalam meningkatkan kedisiplinan guru apabila bisa dilaksanakan secara maksimal, maka motivasi guru untuk berprestasi akan tinggi, sehingga pendidikan di sekolah dasar otomatis akan berkembang pesat. Dalam pengelolaan personalia meliputi rekruitmen, penempatan, pengembangan, penghargaan, merit system, peremajaan, dan lingkungan yang kondusif, tetapi karena keterbatasan waktu maka fokus yang akan dikembangkan dalam penelitian ini yaitu pengembangan guru, insentif (penghargaan) guru, merit system, dan lingkungan yang kondusif. Dalam penelitian ini untuk rekruitmen, penempatan, dan peremajaan tidak dikembangkan karena keterbatasan waktu. Fokus kedisiplinan guru yang akan dikembangkan dalam penelitian ini yaitu kedisiplinan waktu, disiplin terhadap peraturan, dan disiplin terhadap peningkatan usaha bekerjasama.

Menurut Tim dosen Administrasi Pendidikan UPI (2009: 230) menyatakan bahwa manajemen merupakan bekerja dengan sekelompok orang untuk mencapai tujuan organisasi dengan pelaksanaan fungsi-fungsi perencanaan (planning), pengorganisasian (organizing), penyusunan personalia (staffing), pengarahan dan kepemimpinan (leading) dan pengawasan (controlling). Sedangkan pendapat yang lain, Mulyasa (2004: 7) menyatakan bahwa manajemen adalah suatu proses dalam pengembangan kerja sama sekelompok orang untuk mencapai tujuan yang hendak dicapai. Sedangkan Flippo (Hasibuan 2009: 11) mengemukakan Personnel management is planning, organizing, directing, and controlling of the procurement, development, compensation, integration, maintenance, and separation of human resources to the end that individual, organizational and societal objectives are accomplished. Manajemen personalia adalah perencanaan, pengorganisasian, pengarahan, dan pengendalian dari pengadaan, pengembangan, kompensasi, pengintegrasian, pemeliharaan, dan pemberhentian karyawan dengan maksud terwujudnya tujuan perusahaan, individu, karyawan, dan masyarakat.

Dari penyataan para ahli di atas dapat disintesiskan bahwa manajemen adalah suatu proses pengendalian sekelompok orang dalam merencanakan (planning), mengorganisasikan (organizing), memimpin (leading), mengendalikan (controlling), dan inovasi (innovating) sebagai upaya dalam mencapai tujuan yang ditetapkan.

Pengembangan personalia khususnya guru yang menjadi ujung tombak pendidikan merupakan pilar utama dalam pelaksanaan implementasi manajemen personalia. Dalam kaitan implementasi manajemen personalia tersebut, Pidarta (2011: 115) menyatakan pengembangan personalia pendidikan membutuhkan perhatian ke dalam yaitu terhadap diri sendiri, terutama pengetahuan yang sudah lama atau usang dan pelaksanaan tugas yang ketinggalan jaman. Ahli lain berpendapat bahwa manajemen personalia meliputi beberapa kegiatan yang mencakup rekrutmen personalia, penempatan, pelatihan dan pengembangan, penghargaan, merit system, peremajaan dan lingkungan kerja yang kondusif (Flippo, 1992: 24). Sedangkan Soetjipto dan Kosasi (2004: 47) mengemukan bahwa manajemen personalia meliputi pengembangan guru yang dapat dilakukan baik secara perseorangan maupun kelompok, kegiatan tersebut dapat berupa: tugas belajar, kursus, seminar, diklat, dan penataran.

Berdasarkan uraian-uraian di atas dapat disimpulkan bahwa manajemen personalia suatu rangkaian kegiatan yang mencakup rekrutmen personalia, 
penempatan, pelatihan dan pengembangan, penghargaan, merit system, peremajaan dan lingkungan kerja yang kondusif yang dapat dilakukan secara kelompok maupun perseorangan dalam rangka pengembangan guru.

Unsur-unsur dalam manajemen personalia atau manjemen sumber daya manusia yaitu terdiri atas:

1. Pengembangan Guru

Pengembangan pegawai atau pembinaan pegawai adalah usaha yang dilakukan lembaga pendidikan bertujuan untuk memajukan dan meningkatkan mutu tenaga personalia yang berada dalam lingkungan sekolah baik tenaga edukatif maupun tenaga administratif (Arikunto, 2008: 232). Sedangkan Sirkula (Pidarta, 2011: 119) menyatakan bahwa pengembangan guru yang dilakukan oleh lembaga pendidikan melalui pendidikan dan pelatihan akan meningkatkan kuantitas dan kualitas output yang akan meningkatkan moral, meningkatkan kesejahteraan atau penghasilan guru, dan kesehatan guru maupun anggota keluargaanya.

Selaras dengan Pidarta (2013: 282) mengemukakan ada beberapa tempat yang digunakan untuk pengembangan profesi guru yaitu:

a. Dengan belajar sendiri di rumah.

b. Belajar di perpustakaan khusus untuk guru atau perpustakaan umum.

c. Persatuan guru bidang studi.

d. Pertemuan-pertemuan ilmiah.

e. Belajar secara formal pada jenjang $\mathrm{S} 1$, S2, atau S3.

f. Pertemuan organisasi profesi.

g. Kompetisi-kompetisi ilmiah.

\section{Lingkungan yang Kondusif}

Soetjipto dan Kosasi (2004: 47), berkenaan dengan lingkungan yang kondusif menyatakan bahwa lingkungan kerja yang kondusif adalah lingkungan kerja yang dapat menciptakan hubungan yang harmonis antar semua personil, yaitu hubungan kepala sekolah dengan guru, guru dengan guru, kepala sekolah atau guru dengan semua personil lainnya di sekolah serta terjadi hubungan yang harmonis antara semua personil dengan semua peserta didik.

Semangat dan kegairahan kerja para karyawan dalam melaksanakan tugas-tugas dipengaruhi oleh banyak faktor. Faktorfaktor yang dapat mempengaruhi tersebut antara lain adalah jumlah dan komposisi dari kompensasi yang diberikan, penempatan yang tepat, latihan rasa aman di masa depan, mutasi, promosi (Nitisemito, 1996: 96).

\section{Insentif}

Hasibuan (2002: 121) menyatakan bahwa kompensasi berfungsi sebagai ikatan kerja sama, pengadaan yang efektif, motivasi, kepuasan kerja karyawan, stabilitas karyawan, serta serikat buruh dan pemerintah. Dalam hal ini sebuah organisasi atau sekolah harus mempunyai pedoman dalam penetapan kompensasi yang tetap, karena masalah kompensasi merupakan masalah yang penting dan masalah yang komplek. Pedoman dalam sistem pemberian kompensasi meliputi individualitas, proses keputusan terbuka, imbalan yang berdasarkan kinerja, dan sistem kepantasan yang merata (Sastrohadiwiryo, 2002: 189).

Penghargaan diberikan kepada guru dalam rangka peningkatan kinerja yang bersifat positif dan produktif. Dalam penghargaan kepada guru, Pidarta (2005: 56) menyatakan, bagi personalia yang memperoleh penghargaan perlu diperhatikan hal sebagai berikut: (a) kesempatan untuk melaksanakan fungsi kepemimpinan; (b) kesempatan untuk bertanggung jawab secara lebih besar; dan (c) kesempatan untuk ikut dalam perencanaan kurikulum. Motivasi yang mendasar bagi pegawai atau guru yaitu mencari nafkah sehingga penghargaan atau insentif ini menjadi sesuatu yang penting 
bagi kelangsungan kehidupan pegawai atau guru tersebut.

Menurut Schlur dan Jackson (Pfeffer, 2002: 256) menyatakan pelaksanaan merit system akan berjalan efektif apabila memenuhi 3 syarat utama yaitu: (a) menentukan dan mengukur kinerja; (b) menentukan imbalan (pengakuan atau uang, besarnya imbalan, bentuk pembayaran); (c) mendapatkan penerimaan karyawan. Selanjutnya pemberian bonus bertujuan untuk meningkatkan proses pembelajaran, kinerja, dan meningkatkan prestasi kerja guru dalam melaksanakan jabatan sesuai dengan profesinya (Depdiknas, 2000: 14). Selain itu Pidarta (2011: 62) juga menyatakan bahwa kesejahteraan personalia diberikan untuk meningkatkan untuk meningkatkan taraf hidup personalia, sehingga kegairahan kerja juga akan semakin meningkat.

Lawler (Nawawi 2001: 130) menyatakan bahwa banyak memberikan sumbangan pikiran bagai pemahaman kita tentang merit system sebagai sebuah bonus diluar gaji dan insentif. Senada dengan Wexley \& Yukl (1992: 331) menyatakan bahwa merit system sebagai bonus di luar gaji dan insentif. Pelaksanaan merit system akan berjalan dengan baik, apabila pelaksanaan tersebut didasarkan pada: (a) pengukuran yang realistik dan akurat dari kinerja seseorang; (b) menciptakan suatu keyakinan antar karyawan, bahwa cara untuk meraih merit system tinggi yaitu dengan peningkatan kinerja dan motivasi kinerja yang tinggi; (c) pelaksanakan pembedaan yang jelas antara guru yang berprestasi luar biasa dengan guru yang berprestasi rendah, sehubungan dengan jumlah bonus yang diberikan kepada guru yang berprestasi tersebut.

Kerlinger dan Pahazur (Marjono, 2007: 7) mengemukakan umumnya disiplin yang baik, yaitu apabila seseorang datang ke kantor dengan teratur dan tepat waktu, apabila mereka berpakaian serba baik pada menggunakan bahan dan perlengkapan dengan hati-hati, apabila mereka menghasilkan jumlah dan kualitas pekerjaan yang memuaskan dan mengikuti cara-cara kerja yang ditentukan.

Menurut Simamora (1997: 66) disiplin adalah prosedur yang mengoreksi atau menghukum bawahan karena melanggar peraturan atau prosedur. Disiplin digunakan para manajer untuk berkomunikasi dengan karyawan agar mereka bersedia untuk mengubah suatu perilaku serta sebagai suatu upaya untuk meningkatkan kesadaran dan kesediaan seseorang menaati semua peraturan perusahaan dan norma-norma sosial yang berlaku. Senada dengan Hasibuan (2009: 193) berpendapat bahwa kedisiplinan adalah kesadaran dan kesediaan seseorang menaati semua peraturan perusahaan dan norma-norma sosial yang berlaku.

Terdapat beberapa unsur kedisiplinan yaitu: 1) disiplin terhadap diri sendiri; 2) disiplin waktu; 3) disiplin terhadap peraturan; 4) disiplin terhadap peningkatan usaha kerjasama.

Kaitan antara manajemen personalia dan kedisiplinan sangatlah kuat, dimana keberadaan manajemen personalia yang baik akan berdampak pada kedisiplinan guru yang baik.

\section{METODE}

Penelitian ini akan menggunakan pendekatan kualitatif dan jenis penelitian analisis deskriptif. Peneliti menggunakan pendekatan kualitatif agar lebih bisa menggambarkan realitas yang kompleks. Yang mana kondisi obyektif di lapangan tidak dapat di ambil generalisasi yang prediktif dan mengungkapkannya melalui deskripsi yang dituangkan dalam bentuk uraian mengenai Manajemen Personalia Dalam Meningkatkan Kedisiplinan Guru di Madrasah Ibtidaiyah Negeri (MIN) Kamal Bangkalan. Hasil penelitian ini nanti akan memperoleh gambaran tentang Manajemen Personalia Sekolah dalam Meningkatkan 
Kedisiplinan Guru yang dapat dijadikan pedoman bagi lembaga lain untuk melaksanakan dan mengelolanya khususnya di lembaga pendidikan Madrasah Ibtidaiyah Negeri (MIN) Kamal Bangkalan.

Berikut ini adalah desain penelitian yang peneliti terapkan dalam penelitian ini:

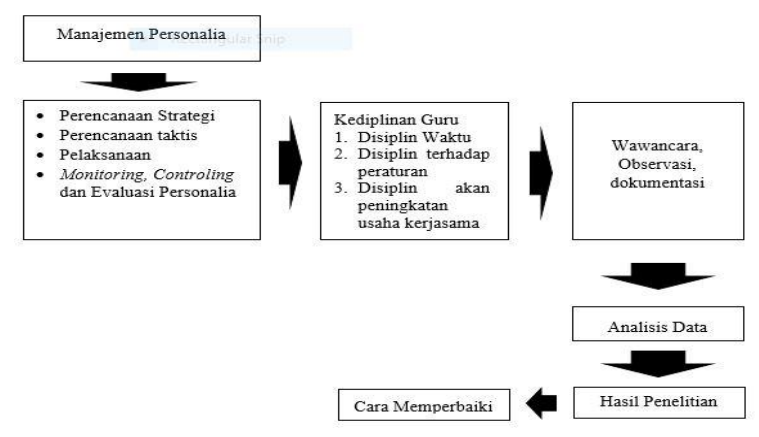

Gambar 1 Desain Penelitian

Informan dalah orang yang memeberikan informasi tentang manajemen personalia dalam meningkatkan kedisiplinan guru yang berlangsung di Madrasah Ibtidaiyah Negeri (MIN) Kamal Bangkalan, yang mana informan ini mempunyai pengalaman tentang latar penelitian kualitatif berfungsi untuk mendapatkan informasi yang maksimun. Informan penelitian dalam penelitian ini adalah: 1) kepala sekolah; 2) wakil kepala sekolah bidang kurikulum; 3) dewan guru dan 4) perwakilan siswa.

Penelitian ini akan dilaksanakan di Madrasah Ibtidaiyah Negeri (MIN) Kamal Bangkalan Jalan Trunojoyo Nomor 5 Desa Banyu Ajuh Kecamatan Kamal Kabupaten Bangkalan. Pengumpulan data penelitian menggunakan metode wawancara mendalam, obsevasi partisipan dan dokumentasi. Teknik analisis data yang digunakan dalam penelitian ini adalah: 1) kondensasi data; 2) penyajian data; dan 3) kesimpulan atau verifikasi.

Sedangkan untuk teknik pengecekan keabsahan data yang digunakan dalam penelitian ini adalah:

1. Credibility, Kredibilitas adalah suatu kriteria yang harus dipenuhi agar data dari informasi yang diperoleh peneliti benar-benar mengandung kebenaran, yang berarti bahwa hasil penelitian yang dilaksanakan dapat dipercaya dan dapat diterima oleh informan yang memberikan informasi selama penelitian berlangsung. Kredibilitas menggunakan beberapa cara: (a) perpanjangan pengamatan; (b) penigkatan ketekunan; (c) triangulasi; (d) analisis kasus negatif; (e) menggunakan bahan refensi; dan (f) mengadakan member check.

2. Tranferability, Merupakan validitas eksternal dalam penelitian kualitatif. Validitas ekstrenal menunjukkan derajat ketepatan atau dapat diterapkannya hasil penelitian ke populasi dimana sampel tersebut diambil.

3. Dependability, Agar penelitian ini dapat dipertahankan dan dapat dipercaya, serta dapat dipertanggungjawabkan secara ilmiah, maka dalam pelaksaannya memerlukan proses uji keakuratan perolehan penelitian yang akan memberikan pertimbangan khusus.

4. Confirmability, Teknik ini digunakan untuk mengadakan pengecekan data berkaitan dengan Manajemen Personalia dalam Meningkatkan Kedisiplinan Guru di Madrasah Ibtidaiyah Negeri (MIN) Kamal Bangkalan dan berbagai aspek yang berkaitan yang diperoleh melalui observasi dan data lainnya untuk memastikan tingkat validitas hasil penelitian yang diperoleh konfirmabilitas audit.

\section{HASIL}

\section{Perencanaan Personalia}

1. Pengembangan guru

Perencanaan pengembangan guru di MIN Kamal Bangkalan dilaksanakan dengan beberapa tahapan, yakni: (a) tahapan penjaringan ide dan gagasan, dalam tahapan ini kepala sekolah melibatkan guru dalam pelaksanaannya dalam rangka menjaring masukan dari para guru perihal bentuk program 
pengembangan guru apa saja yang akan dilaksanakan di MIN Kamal. Dalam prosesnya pelaksanaannya dilakukan di awal tahun pelajaran; (b) pemetaan anggaran, dalam tahapan ini kepala sekolah bersama dengan bendahara sekolah kemudian memetakan anggaran yang dibutuhkan dari setiap kegiatan pengembangan guru yang sudah dihasilkan dari proses sebelumya; (c) penentuan bentuk kegiatan, dalam tahapan ini dikerucutkan perihal fokusfokus kegiatan pengembangan guru yang dihasilkan dari proses sebelumnya, apakah nanti dilaksanakan sendiri, atau dilaksanakan melalui program kerjasama dengan lembaga lain atau hanya ikut serta dalam bagian program pengembangan yang dialkukan oleh instansi luar.

2. Lingkungan yang kondusif

Perencanaan lingkungan kerja yang kondusif di MIN Kamal Bangkalan dilaksanakan dengan beberapa tahapan yang hampir sama dengan pengembangan guru, yakni: (a) tahapan penjaringan ide dan gagasan, dalam tahapan ini kepala sekolah melibatkan guru dalam pelaksanaannya dalam rangka menjaring masukan dari para guru perihal bentuk program penciptaan lingkungan yang kondusif apa saja yang akan dilaksanakan di MIN Kamal. Dalam prosesnya pelaksanaannya dilakukan di awal tahun pelajaran; (b) pemetaan anggaran, dalam tahapan ini kepala sekolah bersama dengan bendahara sekolah kemudian memetakan anggaran yang dibutuhkan dari setiap kegiatan penciptaan lingkungan yang kondusif yang sudah dihasilkan dari proses sebelumya; (c) penentuan bentuk kegiatan, dalam tahapan ini dikerucutkan perihal fokus-fokus kegiatan penciptaan lingkungan yang kondusif yang dihasilkan dari proses sebelumnya, apakah berbentuk program pemantapan hubungan antar guru seperti outbond, atau dilaksanakan melalui program pemetaan kapasitas guru sehingga menghasilkan pembagian tupoksi yang akurat. Dan berbagai macam opsi lainnya.

3. Insentif dan Merit system

Perencanaan berkaitan insentif dan merit system di MIN Kamal Bangkalan dilaksanakan dengan konsep yang sama. Meskipun kedua program ini berbeda, tapi realitas di lapangan berkata demikian. Dimana perencanaan kedua program tersebut lebih didominasi oleh peran dari kepala sekolah. Kepala sekolah sebagai pimpinan lebih berperan sendirian. Hal ini diakibatkan belum adanya bentuk aturan main yang baku perihal dua program di atas yakni insentif dan merit system.

\section{Pelaksanaan Personalia}

1. Pengembangan guru

Pengembangan guru di MIN Kamal Bangkalan melibatkan seluruh elemen guru baik sebagai peserta atau panitia. Pengembangan guru juga dilaksanakan dengan berbagai maca( $m$ mekanisme, yaitu: a) Melaksanakan sendiri dengan pembicara sendiri; (b) Mengadakan kerjasama dengan lembaga lain; dan (c) pengembangan guru yang dilaksanakan oleh pihak luar dan guru MIN Kamal Bangkalan hanya sebagai peserta. Pengembangan guru di MIN Kamal Bangkalan seluruh biaya di tanggung oleh pihak sekolah.

2. Lingkungan kondusif

Pelaksanaan lingkungan yang kondusif di lingkungan MIN Kamal Bangkalan dilakukan dengan berbagai macam cara. Salah satunya adalah tetap menjalin komunikasi yang intens baik yang sifatnya rutin formal dan lainnya. Selain itu cara lainnya adalah dengan membagi tugas disetiap kegiatan atau agenda kepada guru-guru lainnya.

3. Insentif dan Merit system 
Meskipun sudah dilaksanakan, namun Pelaksanaan program insentif dan merit system di MIN Kamal Bangkalan belum mempunyai panduan yang baku atau aturan main atau pakem, sehingga dalam pelaksanaannya pemberian insentif lebih cenderung kepala sekolah selaku pimpinan yang mempunyai pertimbangan sendiri dalam pemberian insentif dan merit system.

\section{Monitoring dan Evaluasi Personalia}

Pelaksanaan monitoring personalia di lingkungan MIN Kamal Bangkalan dilaksanakan hampir dengan pendekatan yang sama. Hal ini dikarenakan sistem monitoring di MIN Kamal Bangkalan di dominasi oleh dua hal. Yang pertama adalah monitoring langsung dari kepala sekolah dan terkadang juga dilakukan bersama dengan pengawas sekolah. Sedangkan yang kedua adalah monitoring yang dilaksanakan dengan konsep rapat.

Sedangkan untuk tahapan evaluasi yang dilaksanakan di MIN Kamal Bangkalan diterapkan melaui dua pendekatan utama yakni formal dimana pelaksanaannya adalah dengan forum rapat resmi yang khusus mengevaluasi setiap tahapan dalam pelaksanaan manajemen personalia Pendekatan evaluasi yang kedua yakni pendekatan informal. Pendekatan ini adalah dengan memanggil individu-individu terkait jika dalam proses manajemen personalia di MIN Kamal Bangkalan terdaat konflik horisontal. Hal tersebut sudah dipikirkan secara matang oleh kepala sekolah sebagai pimpinan dalam mengantisipasi segala kemungkinan yang akan terjadi.

\section{Laporan Personalia}

Pelaporan yang ada di MIN Kamal Bangkalan kaitannya dengan pelaksanaan manajemen personalia adalah dengan 3 cara yakni laporan harian, laporan bulanan dan laporan tahunan. Selain ketiga cara di atas pelaporan yang dilakukan adalah dengan menyusun laporan setiap kegiatan yang dilaksanakan. Kegiatan disini adalah kegiatan yang membutuhkan kepanitiaan dalam pelaksanaannya.

\section{Perencanaan Kedisiplinan}

Perencanaan kedisiplinan di MIN Kamal Bangkalan didasari oleh kebutuhan dengan melihat situasi yang ada. Sehingga harapannya program kedisiplinan di MIN Kamal Bangkalan nantinya tetap sesuai dengan kebutuhan yang berkembang di sekolah tersebut. Di dalam melaksanakan perencanaan program kedisiplinan di MIN Kamal Bangkalan, kepala sekolah selaku pimpinan juga melibatkan guru dan para wakil kepala dalam rangka menyusun aturan main terkait pelaksanaan kedisiplinan di MIN Kamal Bangkalan.

\section{Pelaksanaan Kedisiplinan}

Pelaksanaan kedisiplinan guru terdapat tiga hal pokok yang menjadi aturan main dalam rangka mengawal kedisiplinan guru di MIN Kamal Bangkalan. Ketiga hal tersebut yang pertama adalah Tata Tertib Guru, bagian yang pertama ini lebih khusus memang mengatur semua tentang guru. Yang kedua adalah perihal kode etik guru, kode etik ini juga dikhususkan bagi para guru. yang ketiga adalah aturan main yang berkaitan dengan pembudayaan yang di konsep dengan kegiatan pembiasaan yang ada di MIN Kamal Bangkalan.

\section{Monitoring dan Evaluasi Kedisiplinan}

Pelaksanaan monitoring kedisiplinan guru di MIN Kamal Bangkalan memang dibawah kendali kepala sekolah. Monitoring yang dilaksanakan oleh kepala sekolah lebih banyak bersifat harian. setiap harinya terutama masalah kedisiplinan waktu dimana MIN Kamal Bangkalan sendiri sudah menerapkan sistem Fingerprint sebagai alat bantu utama dalam merekam kedisiplinan guru. kepala sekolah sebenarnya sudah mempunyai buku catatan tersendiri dalam rangka mencatat 
perkembangan kedisiplinan guru setiap harinya.

Sementara untuk sistem evaluasi proram kedisiplinan guru di MIN Kamal Bangkalan dilaksanakan dengan menggunakan dua pendekatan utama. Yang pertama adalah dengan melaksanakan rapat evalusi, dalam konteks ini segala bentuk hal yang berkaitan dengan program kedisiplinan guru dibahas secara menyeluruh, mulai dari pra hingga pasca pelaksanaan program kedisiplinan. Yang kedua dalam rangka mengevaluasi program kedisiplinan guru di MIN Kamal Bangkalan adalah dengan menerapkan tahapan pemberian sanksi bagi guru yang melanggar aturan yang ada.

\section{Laporan Kedisiplinan}

Sistem pelaporan program kedisiplinan guru di MIN Kamal Bnagkalan di konsep dengan empat katagori yakni (a) laporan harian; (b) laporan mingguan; (c) laporan bulanan; dan (d) terakhir yakni laporan semester. Keempat konsep laporan yang dilaksanakan di MIN Kamal Bangkalan di atas adalah dalam rangka mengawal kedisiplinan guru di sekolah tersebut.

\section{PEMBAHASAN}

Tabel 2 Hasil Pembahasan Penelitian

\begin{tabular}{|c|c|}
\hline $\begin{array}{c}\text { Komponen } \\
\text { Standar Ahli }\end{array}$ & uan \\
\hline $\begin{array}{l}\text { A. Perencanaan } \\
\text { Personalia } \\
\text { 1. Pengembangan } \\
\text { guru }\end{array}$ & Peren \\
\hline $\begin{array}{l}\text { Pidarta (2013: 282) } \\
\text { mengemukakan ada } \\
\text { beberapa tempat yang }\end{array}$ & $\begin{array}{l}\text { personalia } \\
\text { dibidang } \\
\text { pengembangan }\end{array}$ \\
\hline $\begin{array}{l}\text { digunakan untuk } \\
\text { pengembangan }\end{array}$ & $\begin{array}{lr}\text { guru yang } \\
\text { dilaksanakan } & \mathrm{di}\end{array}$ \\
\hline profesi guru yaitu: a) & Kamal \\
\hline $\begin{array}{l}\text { Dengan belajar sendiri } \\
\text { di rumah. b) Belajar di } \\
\text { perpustakaan khusus }\end{array}$ & $\begin{array}{l}\text { Bangkalan sudah } \\
\text { melalui tahapan } \\
\text { perencanaan yang }\end{array}$ \\
\hline untuk guru atau & baik. \\
\hline
\end{tabular}

perpustakaan umum.

c) Persatuan guru

bidang studi. d)

Pertemuan-pertemuan ilmiah. e) Belajar

secara formal pada jenjang S1, S2, atau S3. f) Pertemuan organisasi profesi. g) Kompetisi-kompetisi ilmiah.

\section{Lingkungan yang kondusif}

Soetjipto dan Kosasi

(2004:

47) personalia

mengemukakan

dibidang

bahwa beberapa

syarat agar

terciptanya lingkungan

yang kondusif yakni 1)

Menempatkan

personalia secara

benar sesuai dengan

keahlian

dan

keterampilan.

2) baik.

Membina antar

hubungan personalia

yang positif. 3)

Meningkatkan dan

memperlancar

komunikasi.

Menyelesaikan

konflik.

Meningkatkan dan

memelihara persatuan

dan kesatuan

personalia.

\section{Perlunya}

\section{Insentif}

penyusunan aturan

\section{Pidarta (2005: 56)}

main

yang

menyatakan, bagi

personalia yang

memperoleh

penghargaan

berkaitan dengan

standar pemberin

insentif. Pelibatan

guru dalam

diperhatikan hal penyusunan

sebagai berikut: (a) standar tersebut.

kesempatan untuk 


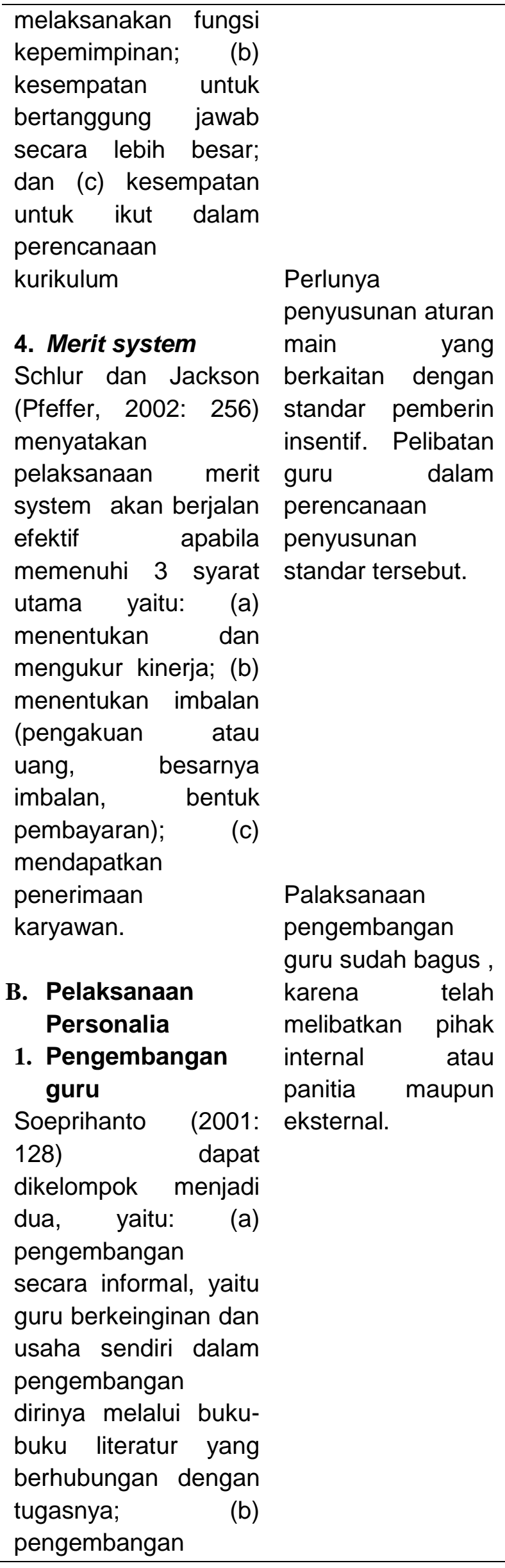

\begin{tabular}{|c|c|}
\hline $\begin{array}{l}\text { formal, yaitu seorang } \\
\text { guru ditugaskan oleh } \\
\text { sekolah atau lembaga } \\
\text { pendidikan untuk } \\
\text { melaksanakan } \\
\text { pendidikan atau } \\
\text { pelatihan tertentu di } \\
\text { lembaga formal. }\end{array}$ & $\begin{array}{l}\text { Palaksanaan } \\
\text { penciptaan } \\
\text { lingkungan yang } \\
\text { kondusif sudah } \\
\text { bagus, karena } \\
\text { telah sesui dengan } \\
\text { teori yang ada. }\end{array}$ \\
\hline
\end{tabular}

\section{Lingkungan yang} kondusif

Soetjipto dan Kosasi (2004: 47), berkenaan dengan lingkungan yang kondusif menyatakan

Lingkungan kerja yang kondusif adalah lingkungan kerja yang dapat menciptakan hubungan yang harmonis antar semua personil, yaitu hubungan kepala sekolah dengan guru, guru dengan guru, kepala sekolah atau guru dengan semua personil lainnya di sekolah serta terjadi hubungan yang harmonis antara semua dengan personil peserta didik. semua

\section{Insentif}

Suryobroto (2004: 53) menyebutkan bahwa Ada beberapa faktor yang harus diperhatikan dalam memberi kompensasi terhadap karyawan, yaitu: (a) kompensasi harus dapat memenuhi kebutuhan minimal, serta sesuai Perlunya
Perlunya

penyusunan aturan main yang berkaitan dengan standar pemberian insentif. Pelibatan guru dalam perencanaan penyusunan standar tersebut. Sehingga tujuan pemberian insentif dapat tercapai dengan maksimal. 


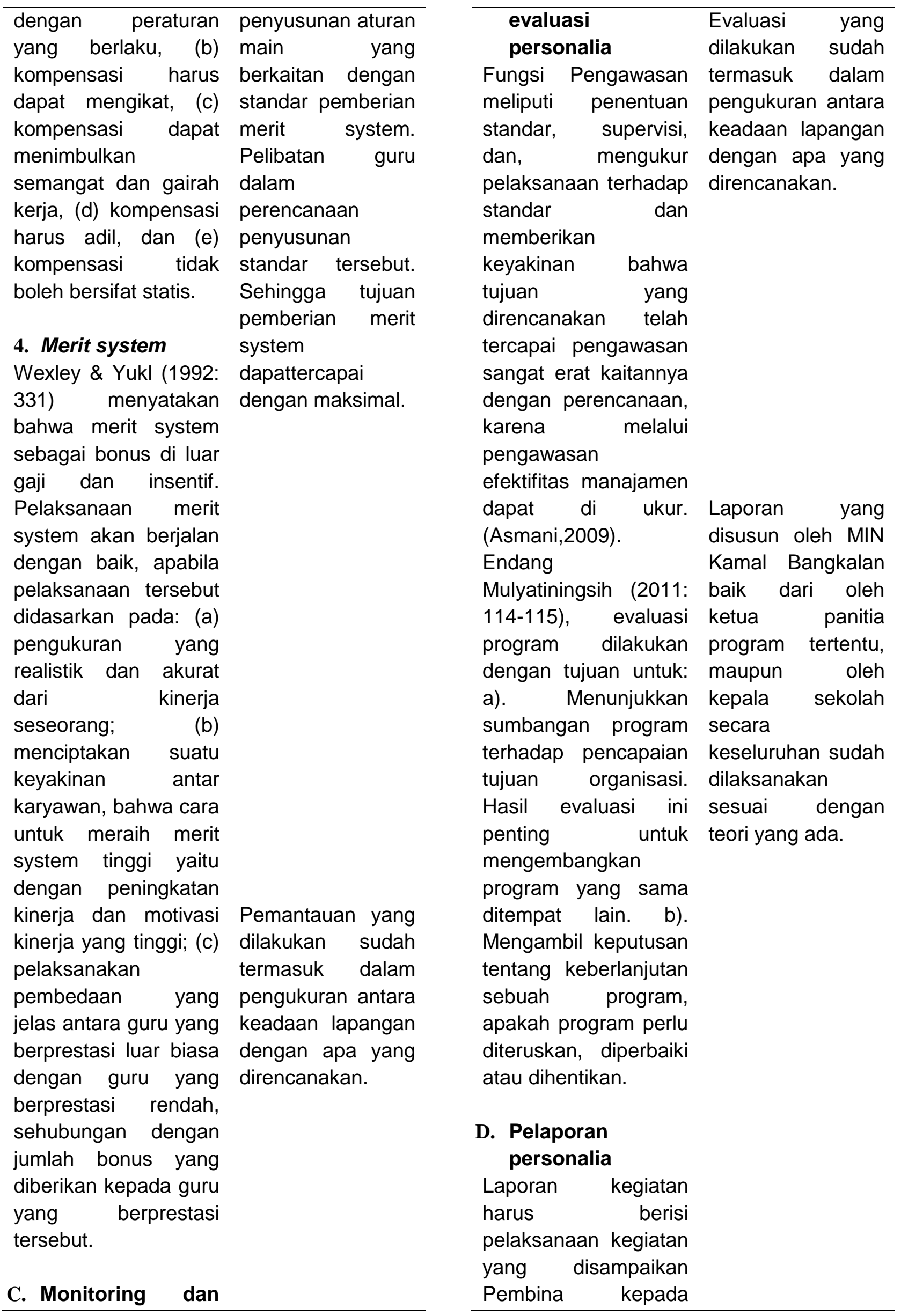




\begin{tabular}{l}
\hline pihak yang memberi \\
tugas $\quad$ sebagai \\
pertanggungjawaban \\
(Materi $\quad$ KML \\
Lemdikanas, 2015)
\end{tabular}

\section{A. Perencanaan \\ kedisiplinan}

\section{Menurut Lembaga}

Ketahanan Nasional

(1997), kedisiplinan dapat terjadi dengan cara: a). Disiplin tidak terjadi dengan sendirinya, melainkan harus ditumbuhkan, dikembangkan dan diterapkan dalam semua aspek menerapkan sanksi serta dengan bentuk ganjaran dan hukuman. b). Disiplin seseorang adalah produk sosialisasi sebagai hasil interaksi dengan lingkungannya, terutama lingkungan sosial. Oleh karena itu, pembentukan disiplin tunduk pada kaidah-kaidah proses belajar. c). Dalam membentuk disiplin, ada pihak yang memiliki kekuasaan lebih besar, sehingga mampu mempengaruhi tingkah laku pihak lain ke arah tingkah laku yang diinginkannya. Sebaliknya, pihak lain memiliki

ketergantungan pada pihak pertama, sehingga ia bisa menerima apa yang

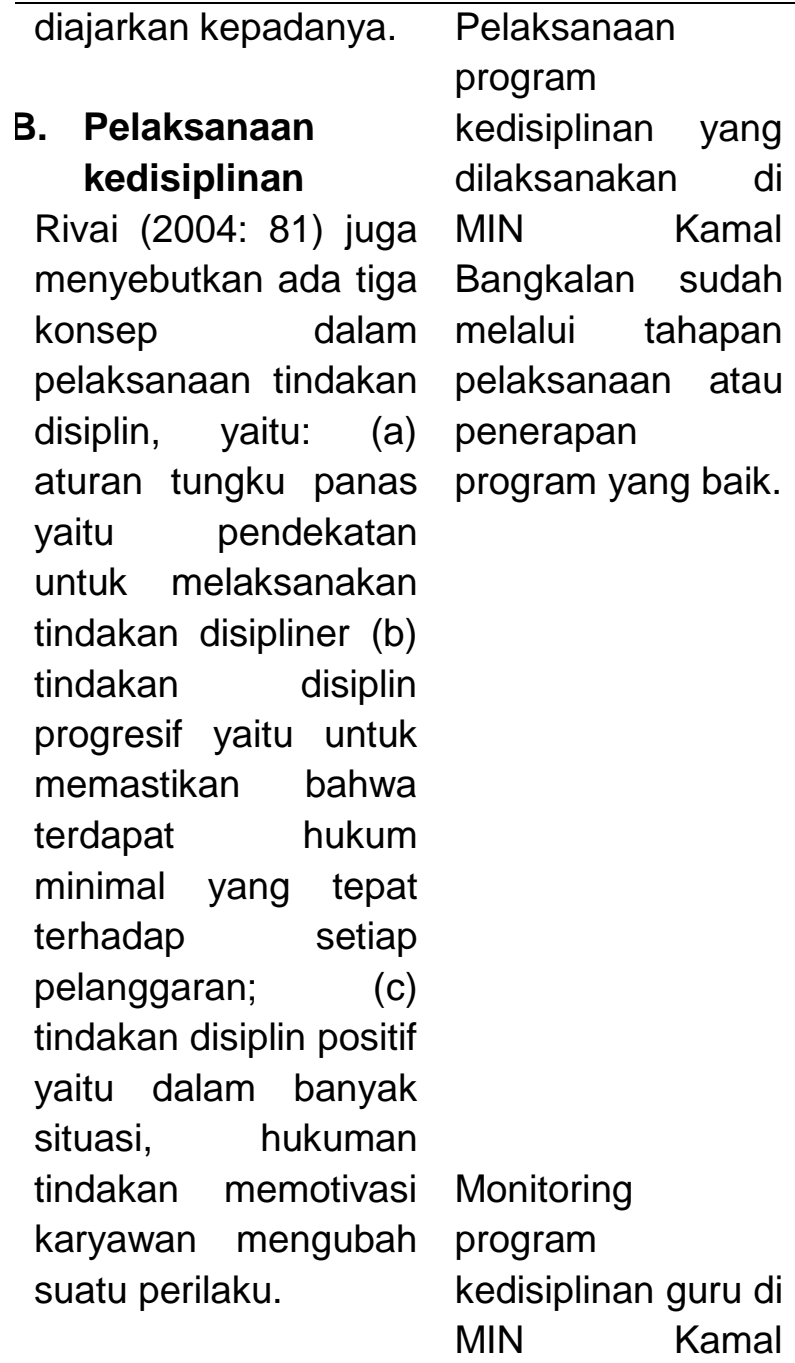

B. Pelaksanaan kedisiplinan

kedisiplinan yang dilaksanakan di Rivai (2004: 81) juga MIN Kamal menyebutkan ada tiga Bangkalan sudah konsep dalam melalui tahapan pelaksanaan tindakan pelaksanaan atau disiplin, yaitu: (a) penerapan aturan tungku panas program yang baik. yaitu pendekatan untuk melaksanakan tindakan disipliner (b) tindakan disiplin progresif yaitu untuk memastikan bahwa terdapat hukum minimal yang tepat terhadap setiap pelanggaran; tindakan disiplin positif yaitu dalam banyak situasi, hukuman tindakan memotivasi karyawan mengubah suatu perilaku.

Monitoring program kedisiplinan guru di MIN Kamal

C. Monitoring dan Bangkalan berjalan evaluasi dengan baik. kedisiplinan

Fungsi Pengawasan meliputi penentuan standar, supervisi, dan mengukur pelaksanaan terhadap standar dan memberikan

keyakinan bahwa tujuan organisasi tercapai. Pengawasan sangat erat kaitannya dengan

Evaluasi program kedisiplinan perencanaan,karena guruyang melalui pengawasan dilakukan kepala efektifitas manajemen sekolah MIN dapat diukur. Kamal Bangkalan (Asmani,2009). berjalan dengan Evaluasi dapat baik. 


\begin{tabular}{lrl}
\hline \multicolumn{2}{l}{ dilakukan } & sebelum, \\
pada saat dan setelah & \\
kegiatan & promosi & \\
selesai. & Sebelum & \\
promosi, lakukan & Laporan program \\
evaluasi dengan cara & kedisiplinan di MIN \\
mengecek semua & Kamal Bangkalan \\
rencana pemasaran & berjalan dengan \\
dengan baik. & baik.
\end{tabular}

\section{Laporan} kedisiplinan

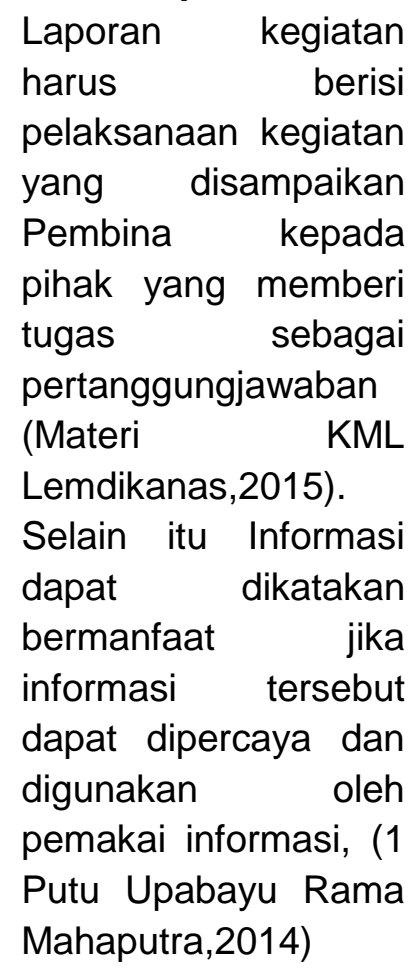

\section{KESIMPULAN}

\section{Perencanaan Personalia}

Perencanaan personalia dilakukan oleh kepala sekolah dengan para wakil kepala sekolah dengan melibatkan seluruh guru yang ada di MIN Kamal Bangkalan. Hasil dari perencanaan tersebut kemudian didapatkan porsi anggaran yang khusus diperuntukkan untuk kegiatan personalia beserta dengan segala bentuk kegiatan yang ada di dalamnya baik yang sifatnya dilaksanakan sendiri, mengajak kerjasama lembaga lain atau dengan hanya melibatkan diri dalam kegiatan personalia dari lembaga lain. Namun demikian anggaran perihal pengembangan guru di MIN Kamal Bangkalan juga terbatas karena harus disebarkan ke segala lini kebutuhan yang ada di MIN Kamal Bangkalan, sehingga dengan demikian penganggaran yang terfokus pada pengembangan guru masih membutuhkan penambahan biaya yang bisa bersumber dari pos-pos anggaran selain dari dana BOS.

\section{Pelaksanaan Personalia}

Pelaksanaan personalia di MIN Kamal Bangkalan sudah dilaksanakan dengan baik meskipun dalam sisi pemberian insentif dan merit system masih dibutuhkan perbikan secara berkala. Pelaksanaan manajemen personalia yang baik di MIN Kamal Bangkalan bisa dilihat dari cara sekolah tersebut dalam mengadakan pengembangan guru dengan bekerjasama dengan lembaga lain. Selain itu peningkatan kerjasama dan jalinan komunikasi antar guru dan lain sebagainya tetap dibina dengan berbagai macam cara seperti mengadakan outbond atau rapat yang sudah ditentukan setiap bulannya. Sedangkan terkait program insentif dan merit system di MIN Kamal Bangkalan, keterlibatan kepala sekolah lebih dominan sedangkan guru jarang dilibatkan di dalamya. Sehingga hasilnya hingga saat ini masih belum ada aturan main yang jelas yang mengatur pemberian insentif maupun merit system di MIN Kamal Bangkalan.

\section{Monitoring dan Evaluasi Personalia}

Dalam memonitoring dan mengevaluasi pemasaran, kepala sekolah MIN Kamal Bangkalan lebih banyak melaksanakan sistem monitoring dengan memantau secara langsung di setiap bagian yang ada yakni mulai dari perencanaan hingga penyusunan laporan. Hal ini dilakukan oleh kepala sekolah agar sistem yang ada dapat bekerja dengan baik dan dapat sesuai antara apa yang direncanakan dengan apa yang dihasilkan nantinya. Sedangkan untuk sistem evaluasinya, kepala sekolah 
mengadakan rapat yang khusus untuk membahas evaluasi dari setiap program personalia yang ada baik yang bersifat formal maupun informal.

\section{Pelaporan Personalia}

Pelaporan dilakukan ketika kegiatan personalia sudah dilaksanakan, dalam proses pelaporan personalia dilakukan oleh ketua panitia kepada kepala sekolah jika program tersebut bersifat kepanitiaan. Sedangkan bila bersifat individu seperti mengirim guru untuk mengikuti suatu pelatihan maka guru tersebut diminta menyusun laporan individu perihal apa yang sudah dilaksanakan selama mengikuti kegiatan tersebut.

\section{Perencanaan Kedisiplinan}

MIN Kamal Bangkalan dalam rangka menciptakan suasana kedisiplinan dari para gurunya melakukan suatu pendekatan khusus yang dilaksanakan dalam rangka penciptaan kedisiplinan guru tersebut. Dalam prosesnya, perencanan kedisiplinan di MIN Kamal Bangkalan dilaksanakan dengan melibatkan seluruh guru. hal ini dilakukan karena nantinya guru bisa merasa memiliki dari setiap hasil perencanaan kedisiplinan yang dilakukan. Karena guru nantinya selain sebagai obyek mereka juga berposisi sebagai subyeknya.

\section{Pelaksanaan Kedisiplinan}

Pelaksanaan kedisiplinan guru di MIN Kamal Bangkalan harus sesuai dengan tiga aturan main yang sudah dihasilkan dari proses perencanan kedisiplinan sebelumnya. Ketiga aturan tersebut adalah tata tertib guru, etika guru dan pembiasaan guru, peserta didik dan tenaga kependidikan yang ada di lingkungan MIN Kamal Bangkalan. Ketiga hal tersebut itulah yang menjadi landasan dasar seluruh kegiatan kedisiplinan guru di MIN Kamal Bangkalan. Namun demikian terdapat satu hal yang perlu dikaji ulang oleh pihak sekolah yaitu berkaitan dengan jam masuk sekolah bagi guru, karena sebagian guru ada yang berharap itu bisa dikaji ulang proses penentuan kebijakannya.

\section{Monitoring dan Evaluasi Kedisiplinan}

Sistem monitoring kedisiplinan guru yang dilaksanakan di MIN Kamal Bangkalan dilaksanakan dengan sistem harian. Dalam prosesnya MIN Kamal Bangkalan sudah mengoperasikan sistem Fingerprint sebagai alat bantu pantau pelaksanaan kedisiplinan guru. selain itu kepala sekolah juga sudah menyediakan buku monitoring khusus yang dipegang sendiri oleh kepala sekolah dalam memantau pelaksanaan kedisiplinan guru di MIN Kamal Bangkalan.

Sedangkan untuk evaluasi program kedisiplinan guru di MIN Kamal Bangkalan, kepala sekolah menerapkan dua langkah, yakni yang pertama adalah dengan mengadakan rapat khusus evaluasi membahas pelaksanaan kedisiplinan di MIN Kamal Bangkalan. Sedangkan yang kedua adalah dengan memberikan tindakan kepada para guru yang melanggar dengan empat tahapan. Satu pemberian surat peringatan pertama, kedua pemberian surat peringatan kedua, ketiga adalah dengan menerapkan pemotongan jam mengajar yang dikalkulasikan dari setiap keterlambatan atau kealpaan guru tersebut, dan yang terakhir keempat adalah dengan melaporkan yang bersangkutan kepada Kemenag Kab. Bangkalan dengan berbagai macam rekomendasi kepada pimpinan lembaga tersebut.

\section{Pelaporan Kedisiplinan}

Pelaporan program kedisiplinan guru di MIN Kamal Bangkalan dikonsep dengan empat tahapan pendekatan. Pertama adalah laporan harian, kedua laporan mingguan dan ketiga adalah laporan bulanan dan yang terakhir keempat adalah laporan semester. Laporan ini digunakan oleh kepala sekolah sebagai bahan evaluasi dan juga bahan laporan kepada pimpinan Kemenag Kab. Bangkalan. 


\section{DAFTAR PUSTAKA}

Ahmed, Maqsood, Istiaq Hussain, Sarsfras Ahmed, M.Qamar ud Din. (2012). "A Study of The Factors Affecting The Profesional Performance of Teacher at Higher Education Level in Khyber Panktunkhwa" Savap International Journal Vol.2, No.2, Marc 2012

Arikunto, S. 2008. Manajemen Pendidikan. Yogyakarta: Aditya Media.

Bahrodin, M. 2007. Pengaruh Kepemimpinan, Motivasi dan Disiplin Kerja terhadap Prestasi Kerja Pegawai Pengadilan Negeri Purworejo. (Tesis Magister tidak dipublikasikan). Purwokerto: Program Pascasarjana Universitas Jenderal Soedirman.

Daryanto, Farid Mohammad. 2013. Konsep Dasar Manajemen Pendidikan di Sekolah. Yogyakarta: PT. Gava Medika.

Decenso, David \& Robbin, Stephen. 2010. Fundamentals of Human Resource Management Tenth Edition. United States of America: John Wiley \& Sons, Inc.

Depdiknas. 2000. Manajemen Peningkatan Mutu Berbasis Sekolah. Jakarta: Dikdiknas.

Depdiknas. 2014. Tingkat Kedisiplinan Guru di Daerah. (Online) (https://acdpindonesia.wordpress.com/2 015/09/01/kedisiplinan-guru-di-daerahrendah/, diakses tanggal 18 Oktober 2015).

Dwidjowinoto, Wahdjudi. 2011. Hand Out Metode Penelitian. Surabaya: Unesa

Faustino, Cardoso G. 2001. Manajemen Sumber Daya Manusia. Yogyakarta: Andi Offset.

Flippo, Edwin. B. 1992. Manajemen Personalia. Jakarta: PT. Glora Aksara Pratama.

Hasibuan, M. S. P. 2009. Manajemen Sumber Daya Manusia. Jakarta: Bumi Aksara.

Listyarti, Retno. 2014. Permasalahan Pendidikan Serta Rekomendasi pemerintahan Baru. Makalah disajikan pada Seminar Komite Nasional Pendidikan. Jakarta, 21 Agustus 2014.

Marjono. 2007. Pengaruh Kedisiplinan, Motivasi, dan Fasilias Sekolah terhadap Prestasi Belajar siswa kelas VIII SMPN 8 Purworejo. (Tesis Magister tidak dipublikasikan). Purwokerto: Unversitas Jendral Soedirman.

Moleong, Lexy. J. 1997. Metode Penelitian Kualitatif. Bandung: PT. Remaja Rosdakarya.

Mulyasa, E. 2004. Menjadi Kepala Sekolah Professional. Bandung: PT. Remaja Rosdakarya.

Peraturan Pemerintah Republik Indonesia No. 53 Tahun 2010. Tentang Kedisiplinan Seorang Pegawai Negeri Sipil. Jakarta: Depdagri.

Peraturan Pemerintah Republik Indonesia No. 74 Tahun 2008 Tentang Guru. Jakarta: Depdiknas.

Pidarta, Made. 2005. Perencanaan Pendidikan Partisipatori Dengan Pendekatan Sistem. Jakarta: PT. Rhineka Cipta.

Pidarta, Made. 2008. Analisis Data Penelitian-Penelitian Kualitatif Dan Artikel. Surabaya: Unesa University Press

Pidarta, Made. 2013. Landasan Kependidikan Stimulus IImu Pendidikan Bercorak Indonesia. Jakarta: PT. Rhineka Cipta.

Pfefer, Jeffrey dkk. 2002. Paradigma Baru Manajemen Sumber Daya Manusia. Yogyakarta: Amara Books.

Robbins, Y. 1990. Essensials of Organizational Behavior. New York: Prentice Hall.

Simamora, Henry. 1997. Manajemen Sumber Daya Manusia. Yogyakarta: STIE YKPN.

Soetjipto dan Kosasi, R. 2004. Profesi Keguruan. Jakarta: PT. Rhineka Cipta.

Soeprihanto. 2001. Manajemen Personalia. Yogyakarta: BPFE. 
Tim Dosen Administrasi Pendidikan UPI .2009. Manajemen Pendidikan. Bandung: Alfabeta.

Triyanto, Agus. 1992. Sketsa Fungsi dan Disiplin Pendidik Menghadapi Era Sekolah Modern. Gema Pendidik, II (5) 8-9.

Undang-Undang Republik Indonesia. No. 20 Tahun 2003 Tentang Sistem Pendidikan Nasional. 